\title{
Analysis of ESP Courses Profile: Bridging the Gap Between ESP Challenges and 21st Century Skills
}

\author{
Bardha Gashi, PhD.Cand. \\ Jasmin Jusufi, PhD. Cand.
}

\begin{abstract}
English has the status of a global language and nowadays, it is "a must tool". In order to be successful in any field of study you need to know the language that is spoken or known worldwide. Therefore, English should be included in any fields of study or disciplines. English for Specific Purposes (ESP) Courses have been offered at the public universities in Kosovo as an elective or compulsory course at many departments, at least for two semesters. Teaching English courses in higher education should be designed based on students' needs by analyzing their level of English and study disciplines, concretely, English for specific purposes courses. Even though, ESP looks as an "easy peasy" issue, in this study has been involved the challenges that ESP teachers and students come across during the complexity of teaching and learning process. In general, this paper also presents an overview of the current situation of ESP courses profile at three public universities in Kosovo. The study has been carried out using three different evaluative research instruments, concretely, has been included a quantitative questionnaire with students and ESP teachers, a qualitative questionnaire (interview) with ten ESP teachers, currently teaching English specific courses at the three universities and also a class observation at three main public universities in Kosovo (Prishtina, Peja and Prizren). Based on the findings, the course content affects directly beliefs, motivation and interests of the students. Hence, ESP courses should be designed based on students' specific language and professional needs in each discipline, while studying at Higher Educational Institutions.
\end{abstract}

Keywords: ESP, challenges, needs analysis, course profile, higher education.

\section{Introduction}

Linguistic strength comes from economic and political power. While the invaders of the world now are technology and commerce, the emphasis is on learning English, specifically, English for specific purposes as "a unified tool" to get across the borders. As (Hutchinson and Waters 1998, p.67) commented, "the effect was to create a whole new mass of people wanting to learn English". Additionally, this mass of people has various language needs. As a result, based on the diverse language needs and purposes are designed ESP Courses.

An instance of this are ESP courses designed for Higher Education Programs, such as Business English, Law English, English for Tourism and Hospitality and many other specific study disciplines should be designed based on specific objectives for homogenous groups of students. Based on this issue Robinson (1991) made an important distinction between students of ESP Courses. "Some are newcomers to their field of work or study who need instruction in the concepts and practices of that field and others are already expert and experienced, but require operational ESP materials and skills, where the instruction and training are taken for granted, and where it is the ability to function in English which is being imparted." Whereas, in Kosovo, faculties of BA (Bachelor) study program, have students that their level of English differs from beginners to advance. Hence, there are newcomers and also experienced students of General English. Facing this fact, designing an ESP course for these students need to be specific having in mind clear objectives as well as learning expectations.

Therefore, the focus of this research is on designing specific or separated courses based on the needs analysis, by analyzing students' language needs and General English knowledge, basically, particular target on learning. 


\subsection{ESP in Kosovo, history and its development}

In Kosovo, English for Specific Purposes has started to be taught in Higher Education System after 1980s, firstly, at some academic units of the University of Prishtina, at that time, the only public University in Kosovo. Since then, in many faculties English has been included as a foreign language in the study programs. In the beginning, the course content has been focused on general English, mainly grammar translation method or excessive translation.

Furthermore, several years ago, ESP teaching in Kosovo was characterized mainly by structural approach. From year to year, different students of different faculties had to use the same textbooks, resources; English courses have been made a uniformity program. Concerning the circumstances that, students come from different background knowledge, studying different fields and the rapid changes and development of the world have an impact on students' interests and needs, which are inevitable, the profile of ESP should be given a conducive approach. Moreover, regarding to development there are many discrepancies to be considered. One of the shortcomings is teaching methodology, such as old teaching theoretical methods rather than practical ones, another issue related to class activities and assignments/projects that could fit students' English interests. Therefore, as mentioned above on this paper examined the challenges of ESP course profile in Kosovo through its history comparing to the current situation and the development of such modules.

\subsection{Course design issues, teaching resources and innovations}

Based on the analysis of the ESP situation in Kosovo, the design of ESP courses at the three public universities is mainly grammar oriented content based on various specific related topics, specifically, including the method of excessive translation of the professional texts. Also, at some faculties and departments, the course is more general English oriented using intermediate level course books such as "Headway", "Opportunities" and other GE resources. Nevertheless, ESP courses are different from General English courses in many aspects. An important question is, whether all the students have the same needs and interests towards learning English for their specific needs. Therefore, the situation should be analysed and assessed in order to design those models of courses. The Grammar Translation Method, particularly, excessive translation of specific professional textbooks and materials such as Business or Law professional texts could not be an appropriate method of teaching. Considering that English is a practical course based on many interwoven exercises and activities, students may not gain or advance their professional English only by translating texts. Furthermore, the design of ESP courses might be based on some principles such as goals, progress and practice by planning a clear course outline at first. Then, the course outline can be expanded into creating a compatible syllabus.

In order to come up with a clear course syllabus, the principles set forth might be expanded, firstly, setting some course objectives and a goal based on what knowledge and abilities the course designer plan or want students to attain. Secondly, teachers at the beginning stage might also plan how to assess students' progress, what kind of tests, assignments or projects could be a clear measurement to evaluate the course process. And the third principle is practice, hereby; practice is the key element of the course and is closely linked to learning objectives as well as learning outcomes. Thus, as English language is considered to be a practical course, it is important to plan such activities and projects that give students opportunities to practice learning and also reflect on it. Hence, activities and assessment criteria might support learning objectives.

In addition, the three public universities are dealing with nearly the same course design issues. As mentioned above on ESP courses are based on a uniformity criteria and the students' interest to attend such courses is very low comparing to the need of English. One of the reasons of this situation might be students' level of English that is predominantly elementary and none of the universities offer additional GE courses.

\section{The importance of implementing a Needs Analysis}

Before starting an ESP course design, teachers of such courses might have consideration on the overall situation of target students, starting from the objective and subjective students' needs as well as their (teachers) needs, and available facilities and accommodation requirements, having in mind that ESP courses are very demanding. Particularly, ESP classes should be based on students' language requirements and also market demands or the need of English for their professional interests. Except the students' requirements, such course design would be better to be based on students' English knowledge and capacities towards successful course completion. 
Needs analysis should serve as a prerequisite for many courses. Since, subject teachers mainly design their courses and plan the syllabuses, hence, the first point to be included in the course outline is students' information in order to assure a flexible syllabus rather than a general or complicated one.

Teachers are considered to be the main part, affecting the course design and its relevance by playing diverse roles. Dudley Evans describes the true ESP teacher or ESP Practitioner (Swales, 1988) in a sense that they are in capability of performing five different roles. These are: 1) Teacher, 2) Collaborator, 3) Course designer and materials provider, 4) Researcher and 5) Evaluator.

While ESP teachers play different roles, they might critically analyze and evaluate the situation of the target group who are going to work with. After that, knowing students' situation and needs it would be easier to set the course goals and objectives towards achievable learning outcomes. Particularly, they might pay attention to the students' capacities and what they could achieve or attain from the course. It cannot be organized an ESP course for intermediate and advance level of students where most of the students do not have English knowledge or only have some basic knowledge from primary and secondary education and expect the course objectives to be achievable. Even though, English is included in the teaching curriculum from the third grade (primary school), and based on the Kosovo's new curriculum from the first grade, the students' English level/knowledge at public universities is mostly at an acquaintance stage. Hence, the ESP teacher by playing diverse roles can prepare an English specific course by knowing and analyzing students' specific English situation and language interests.

\subsection{Raising awareness of ESP teacher training and advancing the system of ESP teaching}

The level of ESP teachers in Kosovo is still at the inception stage, even though, ESP courses has been teaching since 1980s. One of the most important challenges concerning ESP improvement in the current situation at the public Universities in Kosovo is the lack of teacher training and subject instructors. Consequently, ESP classes are more oriented to text translation and learning specific lexicon, or methods chosen by teachers' availability and appropriateness.

Nevertheless, ESP has started to be included in higher academic teaching programs in Kosovo since 1980s, less attention have been paid on ESP teacher training. In order to improve the ESP teaching process such instructors might be organized and encouraged on attending ESP training programs, workshops, seminars and conferences. Firstly, by being aware that teaching English Specific courses is fairly different from General English courses.

Secondly, interacting and cooperating with other developed foreign universities and colleagues could be a 'helping hand' related to this issue.

"ESP teachers find themselves in a situation where they are expected to produce a course that exactly matches the needs of a group of learners, but are expected to do so with no, or very limited, preparation time" (Johns, 1990, p. 91).

Whereas, (Nunan, 1987, p. 75) related to course design preparation, points out that "It seems fairly obvious that if teachers are to be the ones responsible for developing the curriculum, they need the time, the skills and the support to do so. Support may include curriculum models and guidelines and may include support from individuals acting in a curriculum advisory position. The provision of such support cannot be removed and must not be seen in isolation, from the curriculum."

Hence, a triangular including ESP teacher, curriculum advisor/expert and other ESP teachers' collaboration would bring opportunities and facilities for the teacher to come up with a clear course syllabus. Nevertheless, based on the interviews, the absence of teachers' collaboration is evident resulting in having many course design issues that need further improvement.

Considering that things are under an on-going process, changes are inevitable. Thus, teachers should be part of training programs continuously by interacting and collaborating to each-other. Everyone has unexplained queries in mind that needs support to get to the right responses.

\section{Instruments}

There were three different instruments used to collect data during the research. The first instrument was a list of interview questions for ten ESP teachers followed by a questionnaire. Also, a questionnaire distributed to three hundred students/respondents from three universities where the data has been collected, (100 students included from each 
university). The sample of 100 students has been selected because there are a low number of students that attend ESP classes.

Teachers' interview questions as well as questionnaire were focused on the major course design issues and needs analysis.

Whereas, in the students' questionnaire have been involved questions that present the ESP situation, specifically, students' needs and interests towards ESP courses, why they need English in their future careers and also their language knowledge.

\section{Findings and results}

The issues brought out from the interviews with teachers and class observation:

the status of ESP course;

the importance of attending an ESP course;

teacher training programs;

lack of innovations in ESP courses;

teachers cooperation and interactivity;

teaching methodology;

class activities;

the course length;

the number of teachers that teach ESP at university;

faculty resources and facilities for ESP classes, technology;

\section{Figure 1. Students' English language knowledge at University " Hasan Prishtina"}

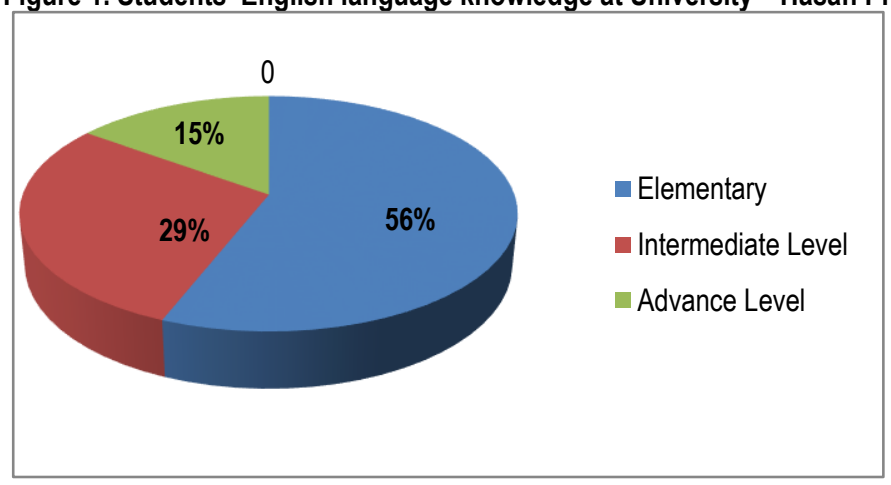

Figure 2. Students' English language knowledge at University of Prizren 


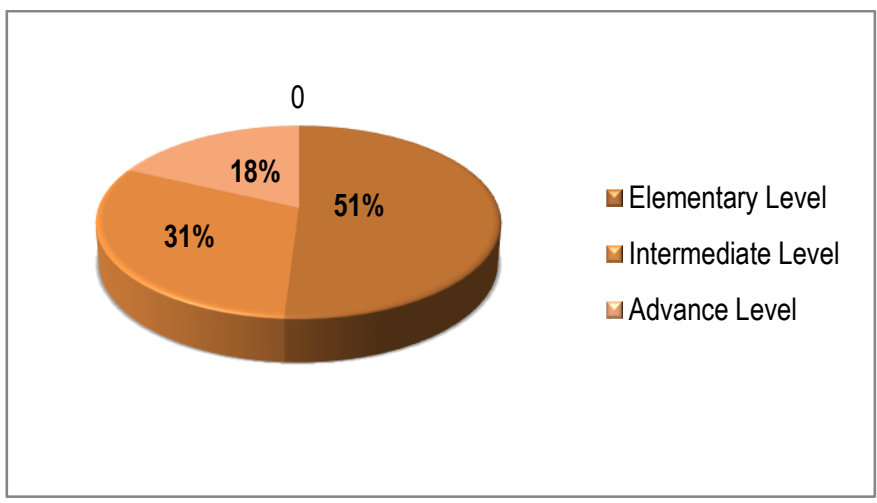

Figure 3. Students' English language knowledge at Public University " Haxhi Zeka" Peja

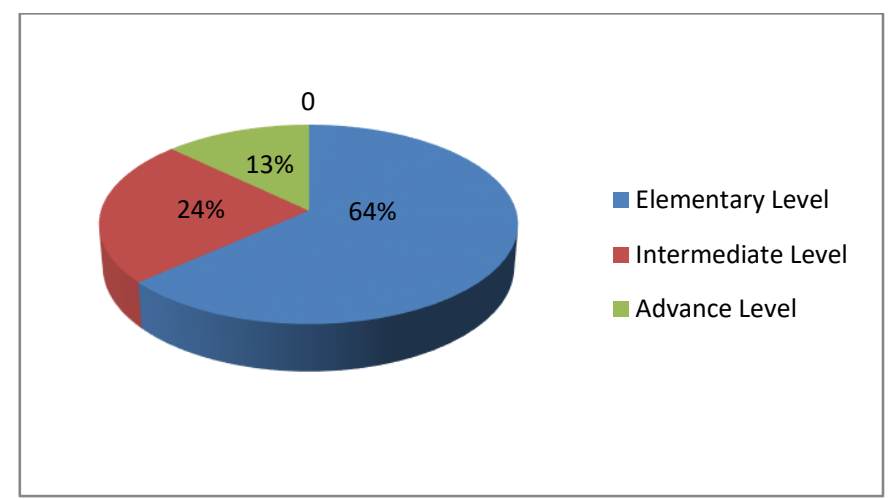

Figure 4. Are you interested in taking an ESP course?

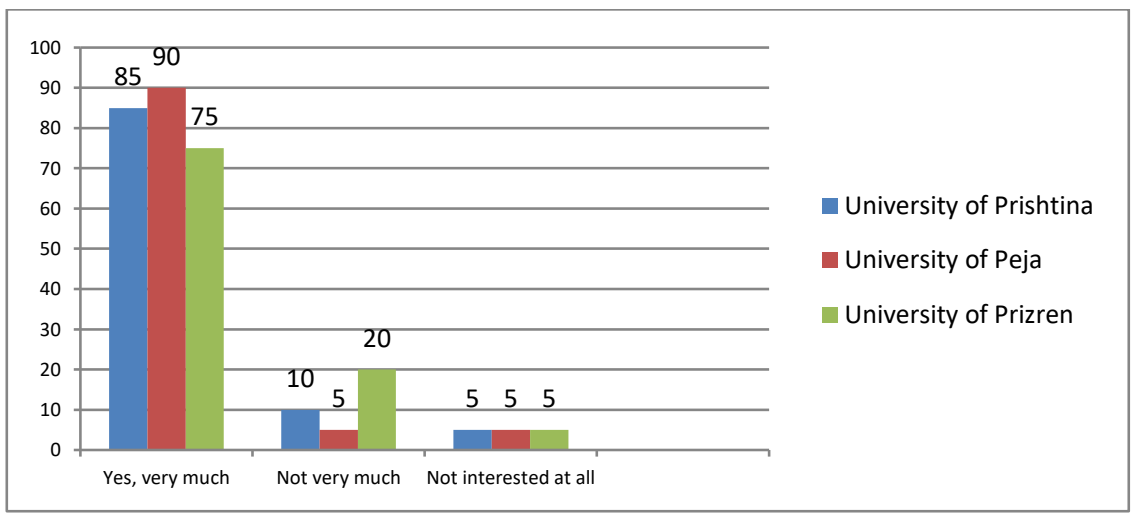

Figure 5. How important do you think ESP is in comparison with other subjects? 


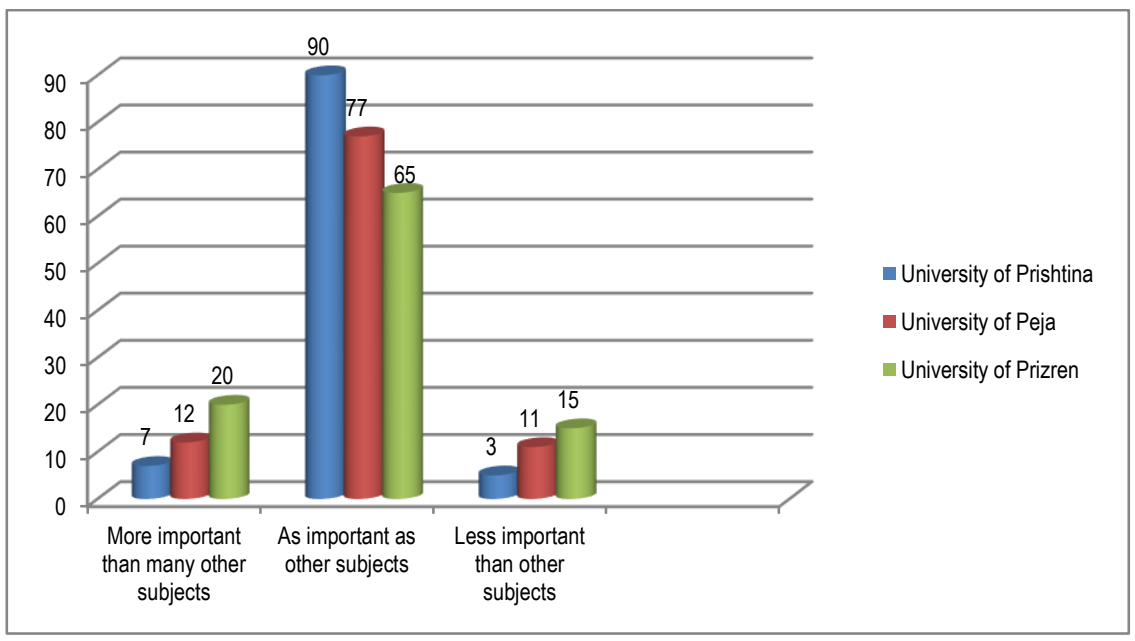

Figure 6. Do you think ESP course will be useful for your future career?

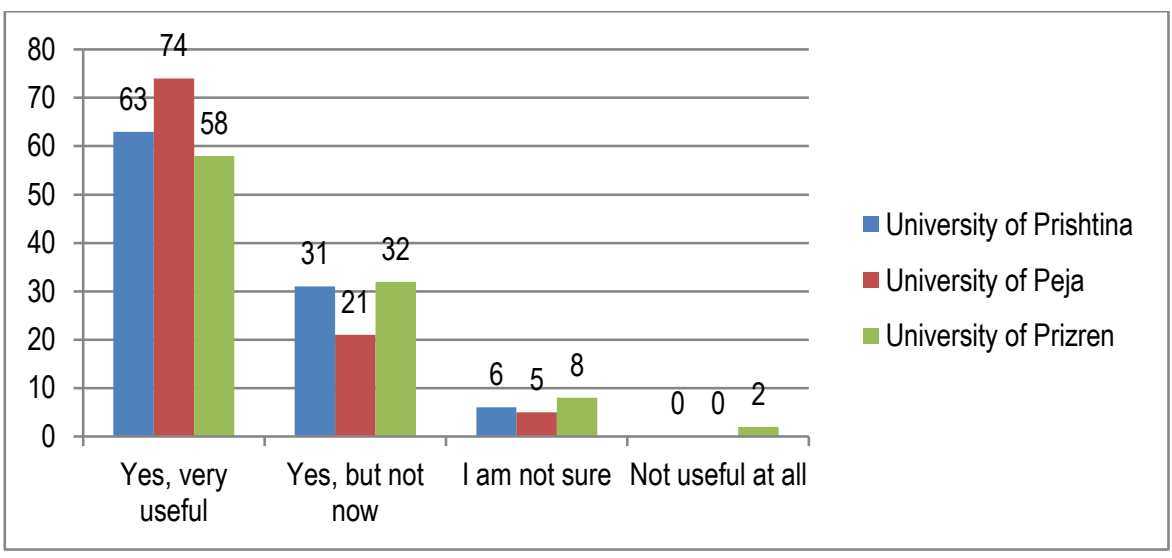

ESP courses have a great importance in the higher education programs. That is proved by the students and based on the study results, where the overwhelming majority of respondents consider ESP courses as important as other subjects. (see Figure. ) Thus, the analysis of the respondents answers offers evidence that from University of Prishtina, $90 \%$ of the students think that ESP is as important as other professional subjects, $7 \%$ replied that ESP is more important than many other subjects and $3 \%$ out of 100 respondents thinks that ESP course is less important than other subjects. Nearly similarly, results from University of Peja gives that evidence, $77 \%$ of respondents think that ESP courses are as important as other subjects, $12 \%$ thinks that Specific English is more important than many other subjects, whereas, $11 \%$ have seen ESP less important than other subjects. Students' beliefs and thoughts from university of Prizren have given these results towards ESP courses importance, $65 \%$ think that ESP is as important as other subjects.

\section{Conclusion}

In general, the education system in Kosovo is undergoing major changes and is on an oscillation process, since Kosovo is a country in transition and most of the projects offered are considered as pilot projects or preliminary studies. The study of the challenges of the ESP courses in the higher education system in Kosovo and its roles in the overall education system 
has become one of the major interests, since more and more English non - native speakers use English as a means for communication in their work setting.

Findings of the study revealed that participants' attitudes towards the usage of English for specific purposes vary in terms of the field of study which is discussed and whether it is important or less important as a course. Major findings indicated that the current situation of ESP course profile, learning and teaching process in the three public universities in Kosovo face many challenges that need to be further developed. Particular attention might be given to the inclusion of $21^{\text {st }}$ century skills and innovations in the ESP curriculum.

In general the study revealed that:

The three public universities face nearly the same challenges, even though the university of Pristina is one of the oldest higher education institution in the country;

The ESP course design, respectively applying innovations in ESP syllabuses is given insufficient attention by the universities;

The lack of a need analysis implementation hinders the ESP course improvement;

Syllabuses for university students in terms of structure and content are nearly the same;

The lack of ESP teachers collaboration and ESP training programs lack may have hindered the improvement and progress;

This paper is an attempt to delineate the picture of current ESP practice in Kosovo's higher institutions. As ESP is an unavoidable trend in ELT and now has become an important composition in higher education, it is crucial to treat the actual issues and address problems arising upon the implementation of innovations in ESP courses.

\section{References}

[1] Krashen, S. (1985). The Input Hypothesis: issues and applications. N.Y.: Longman.

[2] Vygotsky, L. (1978). Mind and society. Cambridge: Harvard University Press.

[3] Graves, K. (1996). Teachers as course developers. England: Cambridge University Press, 1996.

[4] Dudley Evans, T. \& St John, M. J (1998). Developments in English for Specific Purposes: A multi-disciplinary approach. Cambridge: Cambridge University Press.

[5] Jiajing, G. (2007) "Designing an ESP course for Chinese University Students of Business" The Asian ESP Jounal

[6] Wright T. 1991 Language Awareness in Teacher Education Programmes for non -

[7] nature speakers in C. James and P. Garrett (eds)

[8] Gatehouse, K. (2001) Key issues in English for Specific Purposes: (ESP) Curriculum development. TESL Journal Vol. VII, No.10, October 2001

[9] Milevica, B. (2006) Teaching Foreign Language for Specific Purposes: Teacher Development (31 st Annual ATEE conference. pp ), Portoroz, 2006

[10] Pavel V. Sysoyev (2000, p. 3) "Developing English for Specific Purposes Course Using a Learner Centered Approach: A Russian Experience

[11] Robinson, P. (1991). "ESP Today: A Practitioner's Guide”. Hemel Hempstead: Prentice Hall.

[12] Hsiu-Hui Su, "English for Specific Purposes (ESP) in Technological and Vocational Higher Education in Taiwan" Chaoyang University of Technology

[13] Kumari, P. and Md. Rahman, M.(2012) "A Needs Analysis of Underprivileged Technical Students at Indian School of Mine", Dhanbad, India Indian School of Mines, India, ESP Asian Journal, Volume 8, December 2012.

[14] Johns, A., \& Dudley-Evans, T. (1991). English for Specific Purposes: International in scope, specific in purpose. TESOL Quarterly, 25, 297-314.

[15] Holme, R (1996) "ESP Ideas" Harlow, Essex: Longman

[16] Swales, J. (1988). Episodes in ESP. Prentice Hall.

[17] Germizaj, Sh. Hoxha, Sh. (2014) Students' Perception of the ESP Courses at the University of Prishtina

[18] Retrieved on: http://www.uiliria.org/iir/file/22_ShykraneGermizaj_ShpresaHoxha_IIR_2014_1.pdf 